\title{
Investigation of macrophage migration inhibitory factors and gene polymorphisms in patients with psoriasis
}

Psoriazisli hastalarda makrofaj migrasyon inhibitör faktör düzey ve gen polimorfizmlerinin araștırılması

๑ Vildan Manav, ๑ Seval Doğruk Kaçar*, ๑ Pınar Özuğuz**, ๑ Saliha Handan Yıldız***,
๑ Müjgan Özdemir Erdoğan***, ๑ Tülay Köken**** University of Health Sciences Turkey, İstanbul Training and Research Hospital, Clinic of Dermatology, İstanbul, Turkey *Burtom Konur Surgical Medical Center, Department of Dermatology, Bursa, Turkey

**Kırıkkale Private Yașam Hospital, Clinic of Dermatology, Kırıkkale, Turkey ${ }^{* * *}$ Afyon Kocatepe University Faculty of Medicine, Department of Medical Genetics; ${ }^{* * * *}$ Department of Medical Biochemistry, Afyonkarahisar, Turkey

\begin{abstract}
Background and Design: Psoriasis is a multifactorial disease whose causal origin is unclear. Macrophage migration inhibitory factors (MIF) seem pivotal in inflammation and immune response in psoriasis pathogenesis. We aimed to investigate the serum MIF levels and MIF gene polymorphism (rs755622 and rs1007888) in patients with psoriasis.

Materials and Methods: In this study, the association of serum MIF levels and MIF gene polymorphisms with psoriasis were investigated among 100 patients in Turkey. Genotyping was performed by real-time polymerase chain reaction. Serum MIF levels were evaluated by ELISA, and the results were presented in $\mathrm{ng} / \mathrm{mL}$.

Results: The distribution of rs 755622 genotype frequencies in the psoriasis group was: 75,18 , and 4 patients with CC, CG, and GG, respectively. The distribution of rs 1007888 genotype frequencies in the psoriasis group was: 22, 48, and 26 patients with AA, AG, and GG, respectively. There was no statistically significant difference between the two groups. However, there was a statistically significant difference between the mean serum MIF levels of psoriasis patients $(3.29 \mathrm{ng} / \mathrm{mL})$ compared with the control group $(1.08 \mathrm{ng} / \mathrm{mL})(\mathrm{p}<0.001)$.

Conclusion: Significantly higher serum MIF levels were found in patients with psoriasis. However, there was no gene polymorphism association for genetic markers rs755622 or rs 1007888 with psoriasis. Further studies in larger populations are warranted to elucidate the role of MIF and its clinical effects.
\end{abstract}

Keywords: Cytokine, macrophage migration inhibitory factor, MIF, MIF gene polymorphism, psoriasis

Öz

Amaç: Psoriazis etiyolojisi net olmayan multifaktöriyel bir hastalıktır. Psoriazisin patogenezindeki enflamasyon ve immün yanıtta makrofaj migrasyon inhibitör faktör'ün (MiF) yeri önemli görülmektedir. Çalışmamızda, psoriazis hastalarında serum MiF düzeyleri ve MiF gen polimorfizminin (rs755622 ve rs1007888) arasındaki ilişkiyi araştırmayı amaçladık.

Gereç ve Yöntem: 100 psoriazis hastasında serum MiF düzeyleri ile MiF gen polimorfizmlerinin ilişkisi, genotipleme gerçek zamanlı polimeraz zincir reaksiyonu ile araştırıldı. Serum MiF seviyeleri bir ELISA kiti kullanılarak değerlendirildi ve sonuçlar ng/mL olarak verildi.

Bulgular: MiF geni rs755622 polimorfizmi açııından kontrol gurubu ile karşılaştırılı̆̆ında psoriazis hastalarında CC genotipine sahip birey sayısı 75, CG genotipine sahip birey sayısı 18, GG genotipine sahip birey sayısı 4 olarak bulundu. Kontrol grubunda CC genotipine sahip birey sayısı 69, CG genotipine sahip birey sayısı 23, GG genotipine sahip birey sayısı 3 olarak bulundu. íki grup arasında istatistiksel olarak anlamlı fark

Address for Correspondence/Yazışma Adresi: Vildan Manav MD, University of Health Sciences Turkey, İstanbul Training and Research Hospital, Clinic of Dermatology, Istanbul, Turkey

Phone: +90 5334323524 E-mail: drvildanmanav@gmail.com Received/Geliș Tarihi: 07.04.2020 Accepted/Kabul Tarihi: 26.10.2020 ORCID: orcid.org/0000-0002-0044-7414

Cite this article as: Manav V, Doğruk Kaçar S, Özuğuz P, Yıldız SH, Özdemir Erdoğan M, Köken T. Investigation of macrophage migration inhibitory factors and gene polymorphisms in patients with psoriasis. Turkderm-Turk Arch Dermatol Venereol 2021;55:102-7.

(C) Copyright 2021 by Turkish Society of Dermatology and Venereology

Turkderm - Turkish Archives of Dermatology and Venereology published by Galenos Yayınevi. 
saptanmadı. Rs 1007888 poliformizmi açısından kontrol grubu ile karşılaştııılığında psoriazis hastalarında AA genotipine sahip birey sayısı 22, AG genotipine sahip birey sayısı 48, GG genotipine sahip birey sayısı 26 olarak bulundu. Kontrol grubunda AA genotipine sahip birey sayısı 19, AG genotipine sahip birey sayısı 52 , GG genotipine sahip birey sayısı 24 olarak bulundu. İi grup arasında istatistiksel olarak anlamlı fark saptanmadı ( $p=0,454)$. Öte yandan, psoriazis hastalarında ortalama serum MiF düzeyleri 3,29 ng/mL ve kontrol grubunda ortalama serum MiF düzeyleri ise 1,08 ng/mL olarak ölçüldü. İki grup arasında istatistiksel olarak anlamlı fark $\operatorname{vardı}(p<0,001)$.

Sonuç: Psoriazis hastalarında serum MiF düzeyleri anlamlı olarak yüksek bulundu. Bununla birlikte, psoriazis hastalığı ile rs755622 ve rs 1007888 genlerinde herhangi bir gen polimorfizm ilişkisi yoktu. MiF'nin psoriazisteki rolünü ve klinik etkilerini açıklayabilmek için daha büyük popülasyonlarda çalışmalar yapılması gerekmektedir. Anahtar Kelimeler: Sitokin, makrofaj migrasyon inhibitör faktör, MiF, MiF gen polimorfizmi, psoriazis

\section{Introduction}

Psoriasis is an inflammatory skin disease that remits and relapses chronically ${ }^{1,2}$. It was initially regarded as a disease primarily of epidermal keratinocytes but is now recognized as a skin disease caused by immunogenic and polygenic pathogenesis and is associated with comorbidities ${ }^{2}$. The prevalence of psoriasis changes in different populations which ranges from $0.2 \%$ to $4.8 \%^{1}$. Genetic, geographic, and environmental factors are believed to contribute to such differential prevalence ${ }^{1,3}$. Psoriasis is a multifactorial disease whose causal origin is unclear. Several hypotheses have been formulated based on various etiological factors ${ }^{3}$. The dysregulation in cellular immunity drives T-cell stimulation in the skin, and the consequent release of cytokines from T-cells increases the proliferation of keratinocytes. Epidemiological studies have shown that psoriasis is an autoimmune, inflammatory skin disease, and its development is influenced by genetic background ${ }^{3}$. Chronic inflammation in psoriasis contributes to the pathogenesis of comorbidities. In addition, higher rates of smoking, alcohol use, and immunosuppressive therapies used in the treatment of psoriasis also cause comorbidity in patients ${ }^{4}$. Comorbidities associated with psoriasis may also be correlated with genetic background and inflammatory pathways ${ }^{5}$.

Macrophage migration inhibitory factor (MIF) acts as a proinflammatory cytokine and plays an essential role in T-cell activation following antigenic stimulation. Recent studies have elucidated the efficacy of MIF in many autoimmune skin diseases ${ }^{6}$. MIF appears to be pivotal in the pathogenesis of psoriasis as it triggers inflammation and immune response ${ }^{7,8}$. Serum MIF levels in patients with psoriasis lesions were found to be higher than normal 9 .

In this study, we investigated the serum levels of MIF cytokines and gene polymorphisms, which have an important role in the pathogenesis of psoriasis. Several studies reported on the role of MIF in the pathogenesis of psoriasis and rs755622 polymorphisms in different populations ${ }^{10,11}$. Another polymorphism, rs1007888, was found to be associated with insulin resistance, pancreatic $\beta$-cell function, obesity, coronary artery disease, and metabolic syndrome ${ }^{12-15}$. MIF gene polymorphisms in psoriasis have not been studied in Turkey until now, and there is no study in the literature evaluating the relationship between psoriasis and metabolic disease on MIF polymorphisms. Our study aimed to investigate the association between single nucleotide polymorphism of MIF gene- rs755622 and rs 1007888 and comorbidities of psoriasis in a sample of Turkish population.

\section{Materials and Methods}

In this study, 100 patients (aged between; 18 and 60 years) diagnosed with psoriasis (clinically or histopathologically), and 95 age and sex matched healthy volunteers with no family history of psoriasis and no systemic disease or malignancy, were enrolled in the outpatient clinics of Afyon Kocatepe University Faculty of Medicine, Department of Dermatology between June 2014 and January 2015. Patients with inflammatory skin disease elsewhere in the body, those with active infection, psychiatric disease, advanced chronic illness, who had drug induced psoriasis, those who had received chemotherapy within the last five years because of their malignancy and those who had kinship between control and the patient group were not included in the study. In the patient group, systemic and topical treatments for psoriasis were discontinued for 8 and 4 weeks, respectively, before sample collection. Height, weight, waist circumference, psoriasis area and severity index (PASI) scoring, and body mass index (BMI) calculations were performed. Patients were classified into two groups as type 1 (psoriasis onset before 40 years old) and type 2 (at or after 40 years old).

The rights of all participants were protected and written informed consent was obtained before the procedures according to the Helsinki Declaration. The approval from the Ethics Committee of Afyon Kocatepe University (approval number: 2014/04-76, date: 06.03.2014) was obtained for this study. Our study was supported by the Scientific Research Projects Coordination Unit of Afyon Kocatepe University.

\section{Serum quantification of macrophage migration inhibitory factors}

Venous blood samples were taken into $10 \mathrm{~mL}$ Vacutainer SST tubes (Becton Dickinson, France) while the patients were in the sitting position. After waiting for 30 minutes, the tubes were centrifuged at $2000 \mathrm{~g}$ at $4{ }^{\circ} \mathrm{C}$. After centrifugation, serum samples were separated into Eppendorf tubes and stored at $-20{ }^{\circ} \mathrm{C}$ until they were processed further. MIF measurement in serum was performed with a USCN brand Human Macrophage Migration Inhibitory Factor ELISA kit (USCN Life Science Inc., Wuhan, Hubei, PRC). Absorbance reading was performed on a Trinity Biotech Capita Reader (Trinity Biotech PLC, Bray Co. Wicklow, Ireland). Results were presented in $\mathrm{ng} / \mathrm{mL}$. MIF normally circulates at levels between 2 and $10 \mathrm{ng} / \mathrm{mL}$ in human plasma.

\section{Genotyping of polymorphisms}

Blood samples were collected into ethylenediaminetetraacetic acid tubes to prevent coagulation and stored at $4{ }^{\circ} \mathrm{C}$ until DNA isolation. A high pure polymerase chain reaction (PCR) Template Preparation (Roche Diagnostics, Germany) kit was used for DNA isolation. Each sample obtained after isolation, the amount and purity of DNA were determined using a Nanodrop ND-1000 spectrophotometer (Wilmington, USA). Isolated DNA samples were kept at $-20^{\circ} \mathrm{C}$. In this study, genomic DNA was obtained from peripheral blood samples taken from healthy individuals and patients with psoriasis. MIF gene rs755622 and rs1007888 polymorphisms were analyzed using LightCycler ${ }^{\circledR}$ FastStart DNA Master HybProbe (Roche Diagnostics, Germany) and LightSNIP rs755622 and rs1007888 Reagent Mix (TIB 
MOLBIOL, Germany). The fragment containing the MIF gene rs 755622 and rs1007888 polymorphisms was amplified. The amplicon was determined by fluorescence using specific probes that hybridized in the annealing phase of the PCR cycles.

\section{Statistical Analysis}

Statistical analysis was performed using the SPSS 22.0 program. The chi-square test and Student's t-test were used to compare genotype and haplotype frequencies for each MIF polymorphism. P $<0.05$ was considered statistically significant.

\section{Results}

Out of 100 patients, 51 were female, and 49 were male. Of 95 healthy volunteers, 48 were female, and 47 were male. The mean age of the psoriasis patient group was 38.1 years, and the mean age of the control group was 35.6 years. The age of onset was 24.3 years in females and 26.0 years in males. There was no statistically significant difference between the two groups ( $p=0.505)$. The mean waist circumference of the patients was $92.6 \mathrm{~cm}$, the mean BMI was $28.4 \mathrm{~kg} / \mathrm{m}^{2}$, and the baseline PASI score was 11.5.

Twenty-two patients with psoriasis had some form of comorbidity. Six patients had diabetes, 12 had hypertension, 10 had dyslipidemia, 6 had thyroid disease, 1 had coronary artery disease, and 4 had malignancy (thyroid cancer, basal cell skin cancer, gastric carcinoma, and brain tumor). Three patients had diabetes and hypertension, 1 had hypertension and coronary artery disease, 1 had hypertension and dyslipidemia, 1 had thyroid disease and malignancy, 1 had diabetes, hypertension, and dyslipidemia, 1 had hypertension, dyslipidemia, and thyroid disease, and 1 had hypertension, dyslipidemia, and coronary artery disease. All data are presented in Table 1.

\section{Serum MIF levels}

The mean serum MIF levels of the patient and control groups were 3.29 and $1.07 \mathrm{ng} / \mathrm{mL}$, respectively $(p<0.001)$ (Table 2$)$. The mean serum MIF level of 43 patients with a family history of psoriasis was $2.80 \mathrm{ng} / \mathrm{mL}$, while the 55 patients with no such family history showed the MIF level of $3.65 \mathrm{ng} / \mathrm{mL}(p=0.011)$. Serum MIF levels correlated well with waist circumference ( $\left.R^{2}: 0.909\right)$, but not BMI $\left(R^{2}: 0.108\right)$ or PASI ( $\left.R^{2}: 0.419\right)$ (Figure 1). The mean serum MIF levels in type 1 and 2 psoriasis patients were 3.29 and $3.48 \mathrm{ng} / \mathrm{mL}$, respectively $(p=0.931)$. In patients with and without systemic disease, the mean serum MIF levels were 3.31 and $3.33 \mathrm{ng} / \mathrm{mL}$, respectively $(\mathrm{p}=0.666)$. The comparison of serum MIF levels in rs755622 and rs1007888 polymorphisms with the control group is shown in Table 3, 4.

\section{MIF gene polymorphisms}

\section{rs755622 polymorphism}

Genotype and allele comparison of the rs755622 polymorphism between the control and patient groups was presented in Table 5.

When the rs755622 polymorphism of 20 consanguineous patients was examined, 15 patients had the CC genotype, 4 patients had the CG genotype, and 1 patient had the GG genotype ( $p=0.962)$. In 26 patients with first-degree relatives who had psoriasis, the rs755622 polymorphism was examined, and 16, 10, and 0 patients with the CC, $C G$, and GG genotypes, respectively, were observed ( $p=0.004)$. Among patients with type 1 psoriasis, 64, 12, and 2 had the CC, CG, and GG genotypes, respectively. Among patients with type 2 psoriasis, 11, 6,

\begin{tabular}{|c|c|c|}
\hline $\begin{array}{l}\text { Demographic and clinical data } \\
\text { of psoriasis patients }\end{array}$ & \multicolumn{2}{|l|}{ Number of patients } \\
\hline \multirow{4}{*}{ Localization } & Urban & 48 \\
\hline & Suburban & 36 \\
\hline & Rural & 9 \\
\hline & Neighboring province & 7 \\
\hline Consanguineous marriages & \multicolumn{2}{|l|}{21} \\
\hline \multirow{3}{*}{ Family history of psoriasis } & 1. degree & 28 \\
\hline & 2. degree & 19 \\
\hline & Both & 3 \\
\hline Smoking & \multicolumn{2}{|l|}{33} \\
\hline Alcohol use & \multicolumn{2}{|l|}{2} \\
\hline Those who use both & \multicolumn{2}{|l|}{11} \\
\hline $\begin{array}{l}\text { More than } 30 \text { min per day with } \\
\text { sun exposure }\end{array}$ & \multicolumn{2}{|l|}{51} \\
\hline \multirow[t]{5}{*}{ Types of psoriasis } & Chronic local & 39 \\
\hline & Chronic generalize & 38 \\
\hline & Guttate & 17 \\
\hline & Palmoplantar & 5 \\
\hline & Inverse & 1 \\
\hline Nail involvement & \multicolumn{2}{|l|}{33} \\
\hline Joint involvement & \multicolumn{2}{|l|}{9} \\
\hline \multirow[t]{13}{*}{ Comorbidities } & Diabetes mellitus & 6 \\
\hline & Hypertension & 12 \\
\hline & Dyslipidemia & 10 \\
\hline & Thyroid disease & 6 \\
\hline & $\begin{array}{l}\text { Coroner artery } \\
\text { disease }\end{array}$ & 1 \\
\hline & Malignancy & 4 \\
\hline & $\mathrm{DM}+\mathrm{HT}$ & 3 \\
\hline & $H T+C A D$ & 1 \\
\hline & $H T+D L$ & 1 \\
\hline & Thyroid + malignancy & 1 \\
\hline & $D M+H T+D L$ & 1 \\
\hline & $\mathrm{HT}+\mathrm{DL}+$ thyroid & 1 \\
\hline & $H T+D L+C A D$ & 1 \\
\hline
\end{tabular}

and 2 had the CC, CG, and GG genotypes, respectively (between the genotype distributions of type 1 and 2 patients $p=0.059$ ).

For the 75 patients with the CC genotype, the mean waist circumference was $92.09 \mathrm{~cm}$, the mean BMI was $28.4 \mathrm{~kg} / \mathrm{m}^{2}$, and the mean PASI score was 11.66. For the 18 patients with the CG genotype, the mean waist circumference was $95.00 \mathrm{~cm}$, the mean BMI was $28.8 \mathrm{~kg} / \mathrm{m}^{2}$, and the mean PASI score was 11.06. For the 4 patients with the GG genotype, the mean waist circumference was $94.25 \mathrm{~cm}$, the mean BMI was $30.3 \mathrm{~kg} / \mathrm{m}^{2}$, and the mean PASI score was 9.07 . 


\begin{tabular}{|c|c|c|}
\hline Groups & Serum MIF (ng/mL) & p-value \\
\hline \multirow{3}{*}{ Psoriasis patients ( $n=99)$} & Median: 3.29 & \multirow{6}{*}{$<0.001$} \\
\hline & Minimum: 0.36 & \\
\hline & Maximum: 8.82 & \\
\hline \multirow{3}{*}{ Controls $(n=95)$} & Median: 1.07 & \\
\hline & Minimum: 0.14 & \\
\hline & Maximum: 3.09 & \\
\hline
\end{tabular}

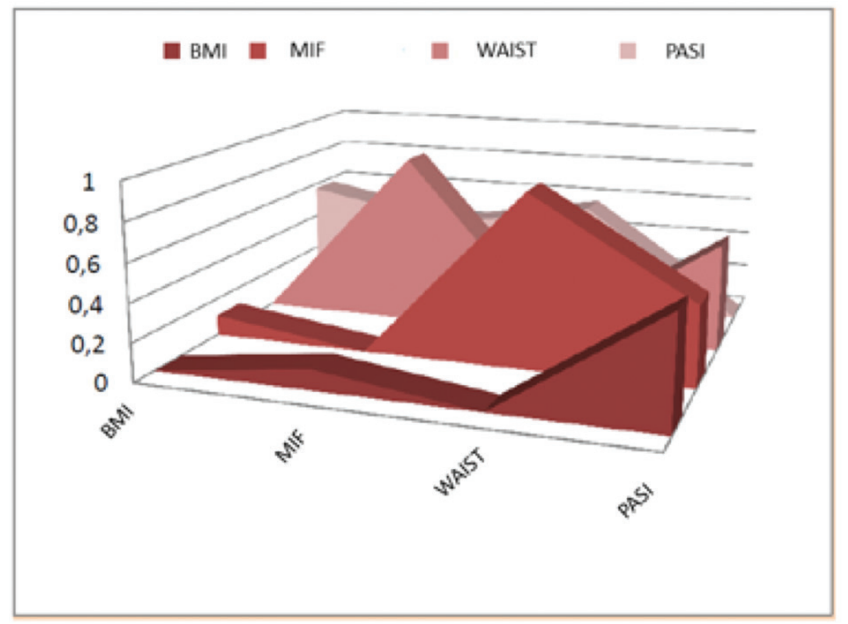

Figure 1. Correlation of BMI, MIF, WAIST, and PASI

BMI: Body mass index, MIF: Macrophage migration inhibitory factors, WAIST: Waist circumference, PASI: Psoriasis area and severity index

\begin{tabular}{|c|c|c|c|c|c|}
\hline \multirow[b]{2}{*}{ Genotype } & \multicolumn{2}{|c|}{ Psoriasis patients } & \multicolumn{2}{|c|}{ Controls } & \multirow[b]{2}{*}{ p-value } \\
\hline & $\mathbf{n}$ & $\begin{array}{l}\text { Serum MIF } \\
(\mathrm{ng} / \mathrm{mL})\end{array}$ & $\mathbf{n}$ & $\begin{array}{l}\text { Serum MIF } \\
(\mathrm{ng} / \mathrm{mL})\end{array}$ & \\
\hline $\mathrm{CC}$ & 74 & 3.31 & 69 & 1.05 & $<0.001$ \\
\hline CG & 18 & 3.21 & 23 & 1.18 & $<0.001$ \\
\hline GG & 4 & 4.98 & 3 & 0.70 & 0.034 \\
\hline
\end{tabular}

When the rs755622 polymorphism of 22 patients with the systemic disease was examined, 18 patients had the CC genotype, and 4 patients had the CG genotype. None of the patients had a GG genotype. There was no statistically significant difference among the groups ( $p=0.873$ ).

\section{rs1007888 polymorphism}

Genotype and allele comparison of the rs1007888 polymorphism between control and patient groups is given in Table 6. When the rs755622 polymorphism of 20 patients with a consanguineous marriage was examined, it was noted that 4 patients had the AA genotype, 9 patients had the AG genotype, and 7 had the GG genotype. In the case of the rs 1007888 polymorphism, in those with type 1 psoriasis, 17,36 , and 24 patients had $A A, A G$, and $G G$ genotypes, respectively. Of those with type 2 psoriasis, 5, 12, and 2 patients had the $A A, A G$,

\begin{tabular}{|c|c|c|c|c|c|}
\hline \multirow{2}{*}{ Genotype } & \multicolumn{2}{|c|}{$\begin{array}{l}\text { Psoriasis } \\
\text { patients }\end{array}$} & \multicolumn{2}{|c|}{ Controls } & \multirow{2}{*}{ p-value } \\
\hline & $n$ & $\begin{array}{l}\text { Serum MIF } \\
(\mathrm{ng} / \mathrm{mL})\end{array}$ & $\mathbf{n}$ & $\begin{array}{l}\text { Serum MIF } \\
(\mathrm{ng} / \mathrm{mL})\end{array}$ & \\
\hline AA & 22 & 3.33 & 19 & 1.08 & $<0.001$ \\
\hline$A G$ & 47 & 3.20 & 52 & 1.16 & $<0.001$ \\
\hline GG & 26 & 3.60 & 24 & 0.86 & $<0.001$ \\
\hline
\end{tabular}

Table 5. Genotype and allele comparison of rs755622 polymorphism between control and patient groups

\begin{tabular}{|c|c|c|c|c|}
\hline $\begin{array}{l}\text { Genotype } \\
\text { frequency }\end{array}$ & $\begin{array}{l}\text { Psoriasis } \\
\text { patients }\end{array}$ & Controls & $x^{2}$ & p-value \\
\hline CC & 75 (77.3\%) & 69 (72.6\%) & - & \multirow{3}{*}{0.612} \\
\hline CG & $18(18.6 \%)$ & $23(24.2 \%)$ & 0.982 & \\
\hline GG & $4(4.1 \%)$ & $3(3.2 \%)$ & - & \\
\hline $\begin{array}{l}\text { Allele } \\
\text { frequency }\end{array}$ & $\begin{array}{l}\text { Psoriasis } \\
\text { patients }\end{array}$ & Controls & $x^{2}$ & p-value \\
\hline$C$ & $168(86.6 \%)$ & $161(84.7 \%)$ & 0.271 & \multirow{2}{*}{0.603} \\
\hline G & $26(13.4 \%)$ & $29(15.3 \%)$ & - & \\
\hline
\end{tabular}

Table 6. Genotype and allele comparison of rs1007888 polymorphism between control and patient groups

\begin{tabular}{|c|c|c|c|c|}
\hline $\begin{array}{l}\text { Genotype } \\
\text { frequency }\end{array}$ & $\begin{array}{l}\text { Psoriasis } \\
\text { patients }\end{array}$ & Controls & $x^{2}$ & p-value \\
\hline AA & $22(22.9 \%)$ & $19(20.0 \%)$ & - & \multirow{3}{*}{0.797} \\
\hline$A G$ & $48(50.0 \%)$ & $52(54.7 \%)$ & 0.454 & \\
\hline GG & $26(27.1 \%)$ & $24(25.3 \%)$ & - & \\
\hline Allele frequency & $\begin{array}{l}\text { Psoriasis } \\
\text { patients }\end{array}$ & Controls & $x^{2}$ & p-value \\
\hline A & $92(47.9 \%)$ & $90(47.4 \%)$ & 0.012 & \multirow[t]{2}{*}{0.915} \\
\hline G & $100(52.1 \%)$ & $100(52.6 \%)$ & - & \\
\hline
\end{tabular}

and GG genotypes, respectively. There was no significant difference between type 1 and 2 ( $p=0.188$ ) groups. Among 22 patients with the AA genotype, the mean waist circumference was $94.60 \mathrm{~cm}$, the mean BMI was $29.1 \mathrm{~kg} / \mathrm{m}^{2}$, and the mean PASI score was 13.20. Among the 48 patients with AG genotype, the mean waist circumference was $91.14 \mathrm{~cm}$, the mean BMI was $27.8 \mathrm{~kg} / \mathrm{m}^{2}$, and the mean PASI score was 11.53. Among the 26 patients with the GG genotype, the mean waist circumference was $94.73 \mathrm{~cm}$, the mean BMI was $29.55 \mathrm{~kg} / \mathrm{m}^{2}$, and the mean PASI score was 9.45 .

When the rs1007888 polymorphism of 22 patients with systemic diseases was examined, 14, 14, and 3 patients had the AA, AG genotype, and GG genotypes, respectively ( $p=0.131)$.

\section{Discussion}

Although psoriasis is a common disease, its etiology and pathogenesis are still an evolving area of investigation. In our study, demographics and some clinical information were found to be consistent with those 
found in the literature. We observed that type 1 psoriasis was more common than type 2 psoriasis, as reported earlier. However, unlike many previous studies, we did not find that psoriasis started at an earlier age in women. Clinically, plaque psoriasis was also higher than other clinical types.

In our study, the mean serum MIF level in patients with psoriasis was $3.29 \mathrm{ng} / \mathrm{mL}$. This level was within the normal range according to the literature ${ }^{6,9}$ but was significantly higher compared with the control group. This difference may be because we used a different brand kit from those used in other studies. We did not find a significant difference between the age of onset of psoriasis and the serum MIF values. Therefore, serum MIF levels were not considered a marker for the differentiation of type 1 (before age 40) and type 2 (at or after age 40) psoriasis. A high degree of correlation was only observed with waist circumference and serum MIF levels ${ }^{15,16}$. In contrast, Herder et al. ${ }^{17}$ noted that in patients with type 2 diabetes, high serum MIF levels were associated with increased BMI.

In psoriasis patients with systemic diseases, a disease-related increase in serum MIF values could not be demonstrated. This lack of correlation may be a function of the short duration of disease in our patients and because we made sporadic MIF measurements.

In our study, serum MIF levels were lower in rs755622 polymorphism with the CC, CG genotypes, and in rs1007888 polymorphism with the AA, AG genotypes compared with the GG genotypes. In studies of patients with psoriatic arthritis and SLE patients, serum MIF levels were found to be higher in individuals with the C allele when rs755622 polymorphism was investigated ${ }^{11,12}$.

A study by Donn et al. ${ }^{12}$ reported that in 225 Caucasian psoriasis patients in England, the MIF gene -173 G>C (rs1007888) polymorphism $\mathrm{G}$ and $\mathrm{C}$ allele frequencies were $79.4 \%$ and $20.6 \%$, respectively. In a Southeast Asia-China study of 240 psoriasis patients, Wu et al. ${ }^{13}$ found no significant difference between MIF gene alleles or genotype frequencies. In addition, the $\mathrm{G}$ allele frequency of $-173 \mathrm{G}>\mathrm{C}$ polymorphism was $76.7 \%$, and the C allele frequency was $23.3 \%$. In a study of 191 Caucasian psoriatic arthritis patients in Canada, the 173 G>C polymorphism $\mathrm{G}$ allele frequency was $27.7 \%$, and the $\mathrm{C}$ allele frequency was $72.3 \%{ }^{15}$. We did not find any significant difference between patients and the control group for genotype and allele frequencies. In the $173 \mathrm{G}>\mathrm{C}$ polymorphism, the $\mathrm{G}$ allele was $13.4 \%$, and the $C$ allele was $86.6 \%$. However, our study was performed with 100 patients with psoriasis, and different results may be obtained in studies with a larger number of patients. In addition, it is called the "flip-flop phenomenon". The flip-flop phenomenon is the result of the linkage disequilibrium. This shows that the genome, including selection, the rate of recombination, and mutation, is strongly influenced by genetic drift, population structure, and racial characteristics.

A study by $\mathrm{Wu}$ et $\mathrm{al}^{13}$ found a higher incidence of $173 \mathrm{C}$ allele in male patients with late-onset psoriasis. Coban et al. ${ }^{16}$ reported in a Turkish population, the CG genotype was found more frequently in male patients. In our study, we did not find any significant difference between the sexes for two polymorphisms; however, we found an increase in the frequency of the $173 \mathrm{G}$ allele in type 2 psoriasis patients. Interestingly, we did not find any significant difference between genotypes when we investigated the comorbidities associated with psoriasis. The lack of systemic disease in patients with the GG genotype, diabetes, thyroid disease in 5 patients with CC genotype and hypertension, dyslipidemia in a patient with CC is not a statistically robust enough finding to imply a high likelihood that this is a protective genotype that warrants further investigation as to the origin of the protective effect.

Studies have shown an association between MIF gene polymorphism and obesity, insulin resistance, and cardiovascular diseases ${ }^{10,16,18-21}$.

Increases in microsatellite recurrences from the MIF gene polymorphism or $-173 \mathrm{G}>\mathrm{C}$ polymorphism were correlated with MIF plasma levels. Similarly, rs1007888 polymorphism may influence the incidence of gestational diabetes and metabolic syndrome in individuals with the GG genotype. We evaluated the polymorphism of the MIF gene rs1007888 for associations with gestational diabetes, diabetes mellitus, metabolic syndrome, and myocardial infarction. We found no significant difference between psoriasis patients with the control group. In the study of Zhan et al. ${ }^{15}$, the GG genotype was reported to be associated with gestational diabetes. Similarly, Aslani et al. ${ }^{18}$ also found this genotype among patients with a family history of diabetes. Tereshchenko et al. ${ }^{19}$ found that this genotype was associated with the incidence of myocardial infarction in Czech women. Herder et al. ${ }^{17}$ found that the rs $1007888 \mathrm{C}$ allele was related to the incidence of type 2 diabetes.

In our study, BMI and waist circumference measurements of patients with the $G$ allele were higher than the $A$ allele in polymorphisms rs1007888 and rs755622. Both polymorphisms may affect the risk factors for comorbidities but not psoriasis. In our study, BMI values and waist circumference measurements of patients with the $G$ allele were higher than the $\mathrm{C}$ allele. However, we observed higher serum MIF levels in patients with the $\mathrm{G}$ allele than the $\mathrm{C}$ allele. This observation can be attributed to the fact that the MIF cytokine is effective during the inflammation process in the pathogenesis and can be replaced by tumor necrosis factor-alpha over time. Therefore, comorbidities are seen more frequently at age 40 and later. Our study found that the $G$ allele was higher in patients with psoriasis aged 40 than those aged 40 years younger. We found higher serum MIF levels in patients with psoriasis history and comorbidities than the healthy individuals. Since PASI values were not correlated with serum MIF levels, we showed that serum MIF levels are ineffective in determining the severity of the disease.

\section{Study Limitations}

The main weakness with this study is that the small number of patients. Since it was made on genetic material, the study should have been conducted on at least 400 patients. Since MIF is a cytokine that is affected by many inflammatory processes, it would be more accurate to work on psoriasis patients without any systemic disease. However, it was almost impossible to find patients with both psoriasis and no additional comorbidities in this age group.

\section{Conclusion}

We found no influence of rs755622 or rs1007888 polymorphisms on the incidence of psoriasis. Serum MIF levels did not correlate with the incidence of hypertension, dyslipidemia, or diabetes in patients with psoriasis in our studies. However, we found a robust, positive correlation between serum MIF levels and waist circumference. The relatively high cost of sequencing has limited the number of polymorphisms examined. With the recent reductions in the cost of sequencing and a 
wider availability of deep sequencing information in wider populations, broader studies of MIF gene polymorphism association with psoriasis and psoriasis comorbidities are warranted.

\section{Ethics}

Ethics Committee Approval: The approval from the Ethics Committee of Afyon Kocatepe University (approval number: 2014/04-76, date: 06.03.2014) was obtained for this study.

Informed Consent: The rights of all participants were protected and written informed consent was obtained before the procedures according to the Helsinki Declaration.

Peer-review: Externally peer-reviewed.

\section{Authorship Contributions}

Concept: V.M., S.D.K., P.Ö., S.H.Y., M.Ö.E., T.K., Design: V.M., S.D.K., P.Ö., S.H.Y., M.Ö.E., T.K., Data Collection or Processing: V.M., S.D.K., P.Ö., S.H.Y., M.Ö.E., T.K., Analysis or Interpretation: V.M., S.D.K., P.Ö., S.H.Y., M.Ö.E., T.K., Literature Search: V.M., S.D.K., P.Ö., S.H.Y., M.Ö.E., T.K., Writing: V.M., S.D.K., P.Ö., S.H.Y., M.Ö.E., T.K.

Conflict of Interest: No conflict of interest was declared by the authors.

Financial Disclosure: The authors declared that this study received no financial support

\section{References}

1. Griffithsm CE, Barkers JN: Pathogenesis and clinical features of psoriasis. Lancet 2007;370:263-71.

2. Van de Kerkhof PCM, Nestlé FO: Psoriasis. In: Bolognia JL, Jorizzo JJ, Cerroni L, editor. Dermatology (Forth edition) London: Elsevier; 2017:138-60.

3. Bawcock AM, Barker JN: Genetics of psoriasis: the potential impact on new therapies. J Am Acad Dermatol 2003;49(Suppl2):51-6.

4. Ni C, Chiu MW: Psoriasis and comorbidities: links and risks. Clin Cosmet Investig Dermatol 2014;7:119-32.

5. Onumah N, Kircik LH: Psoriasis and its comorbidities. J Drugs Dermatol 2012;11(Suppl5):5-10.

6. Grieb G, Merk M, Bernhagen J, Bucala R: Macrophage migration inhibitory factor (MIF): a promising biomarker. Drug News Perspect 2010;23:257-64.

7. Shimizu T: Role of macrophage migration inhibitory factor (MIF) in the skin. J Dermatol Sci 2005;37:65-73.

8. Steinhoff M, Meinhardt A, Steinhoff A, Gemsa D, Bucala R, Bacher M: Evidence for a role of macrophage migration inhibitory factor in psoriatic skin disease. Br J Dermatol 1999;141:1061-6.

9. Shimizu T, Nishihira J, Mizue Y, et al: Macrophage Migration Inhibitory Factor (MIF) serum levels associated with extended psoriasis. J Invest Dermatol 2001:116:989-90.
10. Morales-Zambrano R, Bautista-Herrera LA, De la Cruz-Mosso U, et al: Macrophage migration inhibitory factor (MIF) promoter polymorphisms (-794 CATT5-8 and -173 G>C): association with MIF and TNF in psoriatic arthritis. Int J Clin Exp Med 2014;7:2605-14.

11. De la Cruz-Mosso U, Bucala R, Palafox-Sánchez CA, et al: Macrophage migration inhibitory factor: association of -794 CATT5-8 and -173 G>C polymorphisms with TNF- $\alpha$ in systemic lupus erythematosus. Hum Immunol 2014;75:433-9.

12. Donn RP, Plant $D$, Jury $F$, et al: Macrophage migration inhibitory factor gene polymorphism is associated with psoriasis. J Invest Dermatol 2004;123:484 87.

13. Wu J, Chen F, Zhang X, et al: Association of MIF promoter polymorphisms with psoriasis in a Han population in northeastern China. J Dermatol Sci 2009;53:212-5.

14. Eder L, Chandran V, Ueng J, et al: Predictors of response to intra-articular steroid injection in psoriatic arthritis. Rheumatology (Oxford) 2010;49:136773.

15. Zhan Y, Wang YP, Li C, Liu SG, Gao Q: Association between single nucleotide polymorphism of macrophage migration inhibitory factor-rs1007888 and the pathogenesis of gestational diabetes mellitus. Zhonghua Fu Chan Ke Za Zhi 2013;48:326-9.

16. Coban N, Onat A, Yildirim O, Can G, Erginel-Unaltuna N: Oxidative stressmediated (sex-specific) loss of protection against type-2 diabetes by macrophage migration inhibitory factor (MIF)-173G/C polymorphism. Clin Chim Acta 2015;438:1-6.

17. Herder C, Klopp N, Baumert J, et al: Effect of macrophage migration inhibitory factor (MIF) gene variants and MIF serum concentrations on the risk of type 2 diabetes: results from the MONICA/KORA Augsburg CaseCohort Study, 1984-2002. Diabetologia 2008;51:276-84.

18. Aslani S, Hossein-nezhad A, Maghbooli Z, Mirzaei K, Karimi F: Genetic variation in macrophage migration inhibitory factor associated with gestational diabetes mellitus and metabolic syndrome. Horm Metab Res 2011;43:557-61.

19. Tereshchenko IP, Petrkova J, Mrazek F, et al: The macrophage migration inhibitory factor (MIF) gene polymorphism in Czech and Russian patients with myocardial infarction. Clin Chim Acta 2009;402:199-202.

20. Kim BS, Pallua N, Bernhagen J, Bucala R: The macrophage migration inhibitory factor protein superfamily in obesity and wound repair. Exp Mol Med 2015;47:e161.

21. Sánchez-Zamora YI, Rodriguez-Sosa M: The role of MIF in type 1 and type 2 diabetes mellitus. Journal of Diabetes Research 2014;2014:804519. 